\title{
Article \\ Ecotoxicological Effects of Silver Nanoparticles (Ag-NPs) on Parturition Time, Survival Rate, Reproductive Success and Blood Parameters of Adult Common Molly (Poecilia sphenops) and Their Larvae
}

\author{
Sara Vali ${ }^{1} \mathbb{D}$, Nava Majidiyan ${ }^{2} \mathbb{D}$, Ahmad Mohamadi Yalsuyi ${ }^{1} \mathbb{D}$, Mohammad Forouhar Vajargah $^{3}(\mathbb{D}$, \\ Marko D. Prokić 4 (D) and Caterina Faggio ${ }^{5, *(D)}$
}

check for

updates

Citation: Vali, S.; Majidiyan, N.; Yalsuyi, A.M.; Vajargah, M.F.; Prokić, M.D.; Faggio, C. Ecotoxicological

Effects of Silver Nanoparticles (Ag-NPs) on Parturition Time, Survival Rate, Reproductive Success and Blood Parameters of Adult Common Molly (Poecilia sphenops) and Their Larvae. Water 2022, 14, 144 https://doi.org/10.3390/w14020144

Academic Editor: Heiko

L. Schoenfuss

Received: 9 December 2021

Accepted: 1 January 2022

Published: 6 January 2022

Publisher's Note: MDPI stays neutral with regard to jurisdictional claims in published maps and institutional affiliations.

Copyright: (c) 2022 by the authors. Licensee MDPI, Basel, Switzerland. This article is an open access article distributed under the terms and conditions of the Creative Commons Attribution (CC BY) license (https:/ / creativecommons.org/licenses/by/ $4.0 /)$.
1 Department of Fisheries Sciences, Faculty of Fisheries and Environmental Sciences, Gorgan University of Agricultural Science and Natural Resources, Gorgan 49138-15739, Iran; saravali6868@gmail.com (S.V.); ahmad_m.yalsuyi@yahoo.com (A.M.Y.)

2 Department of Veterinary Medicine, Faculty of Veterinary Medicine, Urmia Branch, Islamic Azad University, Urmia 57169-63896, Iran; navamajidian94@gmail.com

3 Department of Fisheries, Faculty of Natural Resources, University of Guilan, Sowmeh-Sara 43619-96196, Iran; mohammad.forouhar@yahoo.com

4 Department of Physiology, Institute for Biological Research "Siniša Stanković", National Institute of Republic of Serbia, University of Belgrade, 11000 Belgrade, Serbia; prokssima@gmail.com

5 Department of Chemical, Biological, Pharmaceutical and Environmental Sciences, University of Messina, Viale Ferdinando Stagno d'Alcontres, 31-98166 Sant'Agata-Messina, Italy

* Correspondence: cfaggio@unime.it

\begin{abstract}
Nanoparticles (NPs) can display toxicological effects on aquatic organisms. This study investigates ecotoxicological effects of Ag-NPs on reproductive and blood parameters of adult common molly (Poecilia sphenops) and their larvae. During the LC50 96 h test, female fish were exposed to concentrations of $0,5,15,25,35,45$ and $60 \mathrm{mg} \mathrm{L}^{-1}$ of Ag-NPs, while larvae were exposed to $0,3,5,10$ and $15 \mathrm{mg} \mathrm{L}^{-1}$. Finally, we aim to evaluate the effects of $0,5,10$ and $15 \mathrm{mg} \mathrm{L}^{-1}$ of Ag-NPs on parturition time, reproductive success and hematological parameters of the mature fish exposed to sub-lethal concentration during a 62-day period. We also evaluated the survival rate of larvae. The results show a positive correlation between mortality rate and Ag-NP concentration. Values for LC50 $96 \mathrm{~h}$ in adult fish and larvae were $26.85 \mathrm{mg} \mathrm{L}^{-1}$ and $6.22 \mathrm{mg} \mathrm{L}^{-1}$, respectively. A lack of parturition and reproductive success were seen in fish that underwent chronic exposure to Ag-NPs $\left(15 \mathrm{mg} \mathrm{L}^{-1}\right)$. The results show that $\mathrm{RBC}, \mathrm{WBC}$ and hematocrit were significantly decreased in fish exposed to Ag-NPs. In addition, the serum concentrations of total protein, albumin, cholesterol and triglycerides were significantly increased in fish submitted to Ag-NPs (concentrations of 5-15). In conclusion, submitting a fish to higher concentration than $10 \mathrm{mg} \mathrm{L}^{-1}$ has adverse effects on reproductive system and blood parameters.
\end{abstract}

Keywords: blood biochemical parameters; fish; reproductive system; silver nanoparticle

\section{Introduction}

During the recent decade, the different types of nanoparticles (NPs) have extensively used worldwide [1-5]. NPs are defined as materials with a size range of 1-100 nm. NP properties depend on physicochemical characteristics [6], and some are produced in large scales due to their unique properties [7]. The most common NPs for industrial use are based on silver particles, with around 300 different products [8]. The production and use of silver nanoparticles (Ag-NPs) has significantly increased and will increase up to 63\% until 2024 due to their efficiency [9]. Studies have reported an antibacterial efficiency of Ag-NPs [10-13]. Ag-NPs are utilized as an antibacterial agent in different industries, but leakage of Ag-NP products during washing and trough contaminate waters can get into 
the environment [14]. In other words, novel technologies provide better opportunities for human life and health, but these may cause risks for the environment. Increased use of NPs and other chemical materials has increased concerns of their exotoxin effects [15]. Aquatic animals are exposed to Ag-NPs via food, water and sediments [11]. Ag in ionic form induces toxicity for bacteria and can affect aquatic organisms, both freshwater and marine fish, in low concentrations [14]. Since fertilization in fish happens in external environments, Ag-NPs may influence reproductive success [16]. Several studies have reported accumulation of metal NPs in fish organs, followed by changes in homeostasis and reproductive performance [17-19]. Studies have reported that accumulated Ag-NPs in tissues can induce oxidative stress [20]. Toxicological effects of Ag-NPs on aquatic organisms were reported in Oreochromis niloticus [6], rainbow trout [16], and common carp [11]. However, information about the toxicity of several pollutants (such as pesticides and heavy metals) has limitations because their toxicity is highly dependent on the environmental conditions, species, age, size and diet of the organism [21-25].

Poecilia sphenops belongs to the Poecilidae family and the Actinopterygii class. Females are bigger than males [26]. P. sphenops produce broods of 10-140 live young, and total numbers of broods depend on the maturity and size of the female [27]. This fish inhabits freshwater systems. The gestation period is $3-4$ weeks, depending on temperature and stored sperm [26].

Serum biochemical parameters are important biomarkers for showing the health status of fish [28-31]; in addition, hematology is a key tool for assessing the health of different species because it is a reliable and non-lethal index [32,33]. The $\mathrm{LC}_{50} 96 \mathrm{~h}$ test is based on studies that aim to examine the toxic effect of pollutants on aquatic organisms [34,35]. In the current study, we investigated the ecotoxicological effects of Ag-NPs on P. sphenops trough examination of the survival rate of fish, as well reproductive-system and blood-biochemical parameters.

\section{Materials and Methods}

\subsection{Ethical Standard}

The procedures employed for rearing, toxicity and sampling were in agreement with protocols recommended by the ethical committee of Gorgan University of Agricultural Science and Natural Resources (Ethical number 19861). Fish were acclimated with methods for acute toxicity tests as suggested for fish, macroinvertebrates and amphibians [36-38].

\subsection{Preparation}

At the beginning, 350 females and 50 males mature common molly (Poecilia sphenops) were bought from ornamental fish stores in Rasht (Guilan, Iran) and transferred to the laboratory (Faculty of Natural Resources, University of Guilan, Sowmehsara, Guilan, Iran). Male fish were just used for fertilization of the females. Females were distributed into 15 aquariums $(100 \mathrm{~cm} \times 40 \mathrm{~cm} \times 50 \mathrm{~cm})$ and acclimatized to the laboratory condition for 2 weeks. Fish were fed at the rate of $2 \%$ of body weight twice a day with a commercial diet (Ocean Nutrition Breeder, Ocean Nutrition Co., Newark, CA, US). The average weight of fish was $5 \pm 0.5 \mathrm{~g}$. Long-term exposure time was 62 days. Water physicochemical properties included temperature $27 \pm 1^{\circ} \mathrm{C}, \mathrm{pH} 7-7.8, \mathrm{NH}_{3}<0.02 \mathrm{mg} \mathrm{L}^{-1}$, BOD $850 \pm 50 \mathrm{mg} \mathrm{L}^{-1}$, total hardness $200 \mathrm{mg} \mathrm{CaCO}_{3}$ and $\mathrm{NaCl}<1 \mathrm{mg} \mathrm{L}^{-1}$. Nanocid L-2000 (Nanonasb Pars Co., Tehran, Iran) was prepared as a common commercial colloidal solution of silver nanoparticles (Ag$\mathrm{NPs}$ ). Distilled water was used as solvent, and silver density was $1000 \mathrm{mg} \mathrm{L}^{-1}$. According to product specifications of Nanocid, the size of silver nanoparticles was between 20 and $30 \mathrm{~nm}$.

\subsection{Acute Toxicity Test for Adult Fish}

Acute toxicity was conducted as reported by previous studies [4,8]. Female fish were divided into eight treatments $\left(0,5,10,15,25,35,45\right.$ and $60 \mathrm{mg} \mathrm{L}^{-1}$ of Ag-NPs) with 3 replications. Fish were maintained in 24 aquariums $(100 \mathrm{~cm} \times 40 \mathrm{~cm} \times 50 \mathrm{~cm})$ filled 
with $80 \mathrm{~L}$ water. There were 7 fish in each aquarium. The mortality rate for mature fish was calculated at interval times of 24, 48, 72 and $96 \mathrm{~h}$ after addition of Ag-NPs [39,40]. Before the addition of Ag-NPs, water physicochemical properties were controlled. Nominal concentrations of Ag-NP suspension were dissolved in distilled water and added.

\subsection{Reproductive Parameters}

Reproductive parameters were investigated as reported by previous studies [8]. In summary, 20 pairs of adult fish were divided into five groups $\left(0,3,5,10\right.$ and $15 \mathrm{mg} \mathrm{L}^{-1}$ of Ag-NPs) and four replications for 62 days. The concentrations were selected based on $\mathrm{LC}_{50}$ for $96 \mathrm{~h}$. We expected that concentrations would not cause mortality but induce physiological effects in the test time [41]. The water source was replaced daily, and water physicochemical properties were constantly checked. Female fish were kept under a lighting regime of $16 \mathrm{~h}$ light and $8 \mathrm{~h}$ dark [42]. Reproductive success was considered as the number of viable larvae calculated for each pair until the last larva. The survival rate for larvae was calculated at time intervals of 24, 48, 72 and $96 \mathrm{~h}$ after birth of the first larvae. Parturition time of fish was considered from the start of the 62-day period to birth of the last larvae. We used 14 cameras (Axton Wi-Fi camera Model M9021W, North Salt Lake, Utah, US) to record behaviors and movement of fish in each group, and the obtained data were collected daily and reviewed by Adobe After Effect software (AAE CS6).

\subsection{Acute Toxicity Test for Larvae}

Following determination of $\mathrm{LC}_{50} 96 \mathrm{~h}$ of Ag-NPs for mature individuals, 105 larvae (12 h after birth) were submitted to different concentrations of Ag-NPs. One-day larvae were divided into five groups. Nominal concentrations of $\operatorname{Ag}-\mathrm{NPs}\left(0,3,5,10\right.$ and $\left.15 \mathrm{mg} \mathrm{L}^{-1}\right)$ were selected based on the acute toxicity of Ag-NPs for mature fish, in agreement with THE mortality rate of mature fish. Mortality rate was investigated in time intervals of $24 \mathrm{~h}$ from 24-96 h after the addition of Ag-NPs. Water physicochemical properties were checked.

\subsection{Blood Parameters}

On day 63 and after one day of harvesting, blood samples were collected from each group (five female fish) using a syringe and via the stem vein. Blood samples were centrifuged at $3000 \mathrm{rpm}$ for $6 \mathrm{~min}$, and sera were investigated for total protein, albumin, cholesterol and triglyceride using commercial kits of Pars Azmoon (Pars Azmoon corp, Tehran, Iran) with the help of an auto-analyzer (Eppendorf, EPOS, Hamburg, Germany). Glucose was measured by the glucose oxidase methods as reported by previous studies [43]. Parts of blood samples were transferred into heparinized vials for assessment of red blood cell (RBC) count, hematocrit and white blood cell (WBC) count, as reported by previous studies [44].

\subsection{Data Analysis}

Lethal concentrations (in 50\% of the population) in time intervals of $24 \mathrm{~h}$ were investigated by using a probit analysis with a $95 \%$ confidence rate. Data for normality were investigated by Kolmogorov-Smirnov test. Since reproductive and blood parameters were normally distributed, the data were analyzed by one-way ANOVA following post-hoc LSD test. Data were reported as mean \pm SD, and all analyses were run using SPSS software (version 20).

\section{Results}

\subsection{Mortality of Fish}

Results for mortality of mature fish are shown in Table 1. Results did not show any mortality in concentrations of 0 and $5 \mathrm{mg} \mathrm{L}^{-1}$. However, mortality was observed in other treatments and increased with time (Table 1). Results show increased time and concentration caused more mortality so that most mortalities were seen in concentrations of $60 \mathrm{mg} \mathrm{L}^{-1}$ and after $96 \mathrm{~h}$. 
Table 1. Mortality rate (number) of adult common molly (P. sphenops) exposed to Ag-NPs (mg L ${ }^{-1}$ ).

\begin{tabular}{cccccc}
\hline Concentration * & Number & $\mathbf{2 4} \mathbf{h}$ & $\mathbf{4 8} \mathbf{h}$ & $\mathbf{7 2} \mathbf{h}$ & $\mathbf{9 6} \mathbf{h}$ \\
\hline 0 & 21 & 0 & 0 & 0 & 0 \\
5 & 21 & 0 & 0 & 0 & 0 \\
10 & 21 & 0 & 0 & 1 & 2 \\
15 & 21 & 1 & 2 & 5 & 6 \\
25 & 21 & 4 & 6 & 7 & 10 \\
35 & 21 & 1 & 11 & 14 & 15 \\
45 & 21 & 10 & 15 & 18 & 19 \\
60 & 21 & 17 & 19 & 21 & 21 \\
\hline
\end{tabular}

Note: * All concentrations are nominal concentrations.

Results for mortality of larvae show no mortality in control larvae not exposed to AgNPs. Mortality was observed from $3 \mathrm{mg} \mathrm{L}^{-1}$ to $15 \mathrm{mg} \mathrm{L}^{-1}$ (Table 2). The greatest mortality was observed at $15 \mathrm{mg} \mathrm{L}^{-1}$ and $96 \mathrm{~h}$. Results show that an increase in concentrations of Ag-NPs and exposure time were followed by a higher mortality rate.

Table 2. Mortality rate (number) in larvae of common molly (P. sphenops) exposed to Ag-NPs (mg L ${ }^{-1}$ ).

\begin{tabular}{cccccc}
\hline Concentrations * $^{*}$ & Number & $\mathbf{2 4} \mathbf{h}$ & $\mathbf{4 8} \mathbf{h}$ & $\mathbf{7 2} \mathbf{h}$ & $\mathbf{9 6} \mathbf{h}$ \\
\hline $\mathbf{0}$ & 21 & 0 & 0 & 0 & 0 \\
$\mathbf{3}$ & 21 & 1 & 1 & 2 & 3 \\
$\mathbf{5}$ & 21 & 2 & 3 & 4 & 7 \\
$\mathbf{1 0}$ & 21 & 5 & 10 & 15 & 19 \\
$\mathbf{1 5}$ & 21 & 11 & 18 & 21 & 21 \\
\hline
\end{tabular}

Note: * All concentrations are nominal concentrations.

Results in Figure 1 confirm a positive correlation between mortality rate and Ag-NP concentrations for both larvae and adult fish $(p<0.01) 96 \mathrm{~h}$ after exposure to Ag-NPs. The greatest mortality rate was recorded in the highest concentration for larvae and both life stages fish.

Lethal Ag-NP concentrations for common molly in different concentrations and times are shown in Table 3. Based on the findings, lethal concentrations were different for adult fish and larvae. Values for $\mathrm{LC}_{50} 96 \mathrm{~h}$ in adult fish and larvae were $26.85 \mathrm{mg} \mathrm{L}^{-1}$ and $6.22 \mathrm{mg} \mathrm{L}^{-1}$, respectively. Data for lethal and sub-lethal concentrations are presented in Table 3 .

Table 3. Lethal Ag-NP concentrations in common molly (P. sphenops) following 96-h LC 50 of Ag-NPs to adult fish (A) and larvae (L).

\begin{tabular}{|c|c|c|c|c|c|c|c|c|}
\hline \multirow{3}{*}{ Point } & \multicolumn{8}{|c|}{ Concentration $\left(\mathrm{mg} \mathrm{L}^{-1}\right)$ * } \\
\hline & \multicolumn{2}{|c|}{$24 \mathrm{~h}$} & \multicolumn{2}{|c|}{$48 \mathrm{~h}$} & \multicolumn{2}{|c|}{$72 \mathrm{~h}$} & \multicolumn{2}{|c|}{$96 \mathrm{~h}$} \\
\hline & A & $\mathrm{L}$ & A & $\mathrm{L}$ & $\mathrm{A}$ & $\mathrm{L}$ & A & $\mathrm{L}$ \\
\hline $\mathrm{LC}_{10}$ & 22.420 & 6.061 & 17.328 & 4.599 & 13.174 & 3.451 & 10.421 & 2.692 \\
\hline $\mathrm{LC}_{20}$ & 29.889 & 8.967 & 23.850 & 6.526 & 18.779 & 5.079 & 15.968 & 3.904 \\
\hline $\mathrm{LC}_{30}$ & 35.280 & 11.063 & 28.555 & 7.915 & 22.821 & 6.253 & 19.968 & 4.778 \\
\hline $\mathrm{LC}_{40}$ & 39.887 & 12.853 & 32.576 & 9.102 & 26.274 & 7.257 & 23.385 & 5.525 \\
\hline $\mathrm{LC}_{50}$ & 44.193 & 14.526 & 38.196 & 10.212 & 31.103 & 8.194 & 26.580 & 6.223 \\
\hline $\mathrm{LC}_{60}$ & 48.499 & 16.200 & 40.080 & 11.321 & 32.730 & 9.132 & 29.774 & 6.921 \\
\hline $\mathrm{LC}_{70}$ & 53.105 & 17.990 & 44.110 & 12.508 & 36.183 & 10.136 & 33.191 & 7.668 \\
\hline $\mathrm{LC}_{80}$ & 58.497 & 20.086 & 48.815 & 13898 & 40.225 & 11.310 & 37.191 & 8.542 \\
\hline $\mathrm{LC}_{90}$ & 65.974 & 22.991 & 55.339 & 15.824 & 45.830 & 12.938 & 42.738 & 9.754 \\
\hline $\mathrm{LC}_{95}$ & 79.148 & 25.391 & 60.728 & 17.415 & 50.459 & 14.283 & 47.318 & 10.755 \\
\hline
\end{tabular}

Note: ${ }^{*}$ All toxicity values are calculated based on nominal concentrations. 


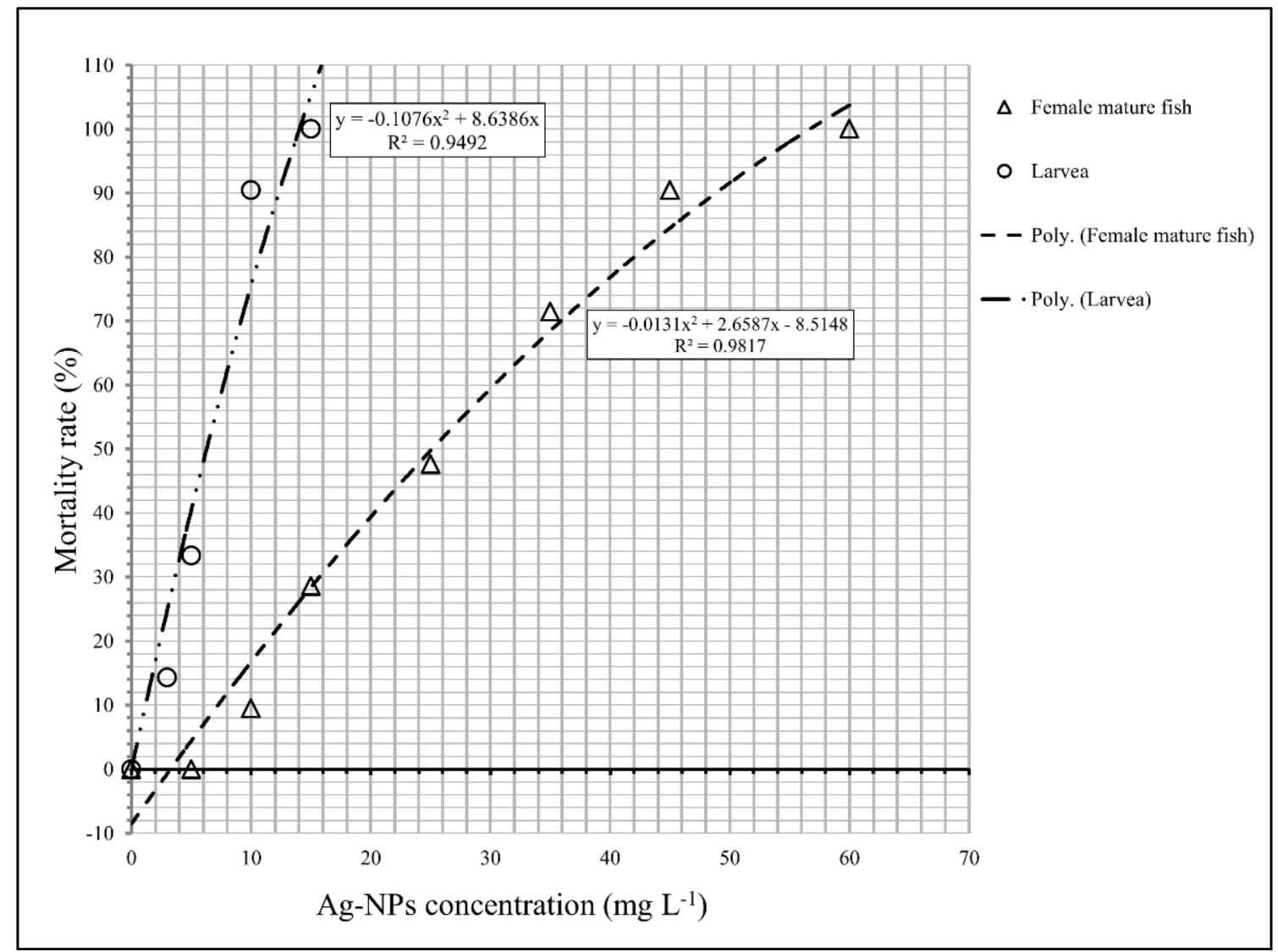

Figure 1. Correlation between nominal lethal concentrations of Ag-NPs, Nanocid L-2000 (Nanonasb Pars Co., Tehran, Iran) with mortality rate of adult common molly (P. sphenops) and their larvae $(p<0.01) 96 \mathrm{~h}$ after exposure to Ag-NPs.

\subsection{Reproductive Parameters}

Results for reproductive parameters are shown in Table 4. Parturition time was longer in fish exposed to concentrations of 15 compared to those treated with $0-10 \mathrm{mg} \mathrm{L}^{-1}$. No parturition nor any reproductive success were seen for fish exposed to $15 \mathrm{mg} \mathrm{L}^{-1}$ of Ag-NPs. Parturition time increased with an increase of exposure dose from $0,3,5$ and $10 \mathrm{mg} \mathrm{L}^{-1}$ of Ag-NPs, respectively. Reproductive success and survival rate were significantly higher in fish that were not exposed to Ag-NPs $\left(0 \mathrm{mg} \mathrm{L}^{-1}\right)$ and decreased with concentrations of 3, 5 and $10 \mathrm{mg} \mathrm{L}^{-1}$, respectively. Results show that the addition Ag-NPs reduced reproductive success and increased parturition time.

Table 4. Parturition time, survival rate and reproduction success of common molly (Poecilia sphenops) and survival rate of their viable larvae (L.) exposed to different concentrations of silver nanoparticles (Ag-NPs, Nanocid L-2000, Nanonasb Pars Co., Tehran, Iran). Exposure time lasted for 62 days for adult fish.

\begin{tabular}{cccc}
\hline Concentration $\left(\mathbf{m g ~ L}^{-1}\right){ }^{*}$ & Parturition Time (Day) & Reproduction (No.) ** & Survival Rate of L. (\%) \\
\hline 0 & $47.67 \pm 0.88^{\mathrm{c}}$ & $60.67 \pm 1.12^{\mathrm{a}}$ & $99.75 \pm 0.25^{\mathrm{a}}$ \\
3 & $49.34 \pm 0.35^{\mathrm{c}}$ & $59.31 \pm 0.89^{\mathrm{a}}$ & $91.67 \pm 2.40^{\mathrm{b}}$ \\
5 & $53.33 \pm 0.33^{\mathrm{b}}$ & $35.33 \pm 0.88^{\mathrm{b}}$ & $75.67 \pm 1.45^{\mathrm{c}}$ \\
10 & $59.00 \pm 0.58^{\mathrm{a}}$ & $13.67 \pm 1.45^{\mathrm{c}}$ & $37.00 \pm 1.15^{\mathrm{d}}$ \\
15 & - & - & - \\
\hline
\end{tabular}

Note: Values are expressed as mean \pm SE. Different letters (a-d) show significant difference between values of the same column $(p<0.05) .{ }^{*}$ All concentrations are nominal. ${ }^{* *}$ Mean number of larvae. 


\subsection{Blood Parameters}

Table 5 shows blood biochemical parameters in fish submitted to Ag-NPs. The results show that RBC, WBC and hematocrit were significantly decreased in fish exposed to Ag-NPs, and the lowest concentrations of examined parameters were seen in adult fish submitted to $15 \mathrm{mg} \mathrm{L}^{-1}$ of Ag-NPs. The serum concentration of glucose was significantly reduced in fish submitted to Ag-NPs (5-15 $\left.\mathrm{mg} \mathrm{L}^{-1}\right)$ compared to control $\left(0 \mathrm{mg} \mathrm{L}^{-1} \mathrm{Ag}-\mathrm{NPs}\right)$. Increased Ag-NPs significantly decreased the serum concentrations of glucose. The serum concentrations of total protein, albumin, cholesterol and triglycerides were significantly increased in fish submitted to Ag-NPs (5-15 mg L $\left.{ }^{-1}\right)$. The highest concentrations for those parameters were observed in the fish exposed to 10 and $15 \mathrm{mg} \mathrm{L}^{-1}$ of Ag-NPs.

Table 5. Results of blood biochemical tests (mean \pm SD) of adult common molly (P. sphenops) after long-term (62 days) exposure to different levels of silver nanoparticles (Ag-NPs, Nanocid L-2000, Nanonasb Pars Co., Tehran, Iran).

\begin{tabular}{|c|c|c|c|c|c|}
\hline Blood Parameters & Control $\left(0 \mathrm{mg} \mathrm{L}^{-1}\right)$ & $3 \mathrm{mg} \mathrm{L}^{-1}$ & $5 \mathrm{mg} \mathrm{L}^{-1}$ & $10 \mathrm{mg} \mathrm{L}^{-1}$ & $15 \mathrm{mg} \mathrm{L}^{-1}$ \\
\hline $\operatorname{RBC}\left(10^{6} \mu \mathrm{L}\right)$ & $2.32 \pm 0.04^{\mathrm{a}}$ & $1.87 \pm 0.2^{b}$ & $1.58 \pm 0.13^{c}$ & $1.30 \pm 0.22^{\mathrm{d}}$ & $1.29 \pm 0.98^{\mathrm{d}}$ \\
\hline WBC $\left(10^{4} \mu \mathrm{L}\right)$ & $2.25 \pm 0.58^{\mathrm{a}}$ & $1.93 \pm 0.2^{b}$ & $1.91 \pm 0.32^{b}$ & $1.62 \pm 0.50^{\mathrm{c}}$ & $1.61 \pm 0.11^{\mathrm{d}}$ \\
\hline Hematocrit (\%) & $45.33 \pm 0.6^{\mathrm{a}}$ & $36.3 \pm 0.5^{b}$ & $36.3 \pm 0.12^{b}$ & $32.6 \pm 0.40^{c}$ & $32.5 \pm 0.80^{\mathrm{c}}$ \\
\hline Glucose (mg/dL) & $4.14 \pm 0.07^{\mathrm{a}}$ & $4.09 \pm 0.14^{\mathrm{a}}$ & $3.25 \pm 0.13^{b}$ & $2.06 \pm 0.10^{\mathrm{c}}$ & $2.01 \pm 0.62^{\mathrm{c}}$ \\
\hline Total protein $(\mathrm{mg} / \mathrm{dL})$ & $1.89 \pm 0.21^{\mathrm{d}}$ & $2.91 \pm 0.15^{b}$ & $2.94 \pm 0.03^{b}$ & $3.58 \pm 0.01^{\mathrm{a}}$ & $3.57 \pm 0.76^{a}$ \\
\hline Triglyceride (mg/dL) & $1.93 \pm 0.06^{\mathrm{d}}$ & $2.23 \pm 0.14^{b}$ & $2.24 \pm 0.02^{b}$ & $2.98 \pm 0.17^{\mathrm{a}}$ & $2.96 \pm 0.3^{a}$ \\
\hline Cholesterol (mg/dL) & $3.97 \pm 0.21^{\mathrm{c}}$ & $3.98 \pm 0.31^{\mathrm{c}}$ & $4.12 \pm 0.04^{\mathrm{a}}$ & $4.15 \pm 0.04^{b}$ & $4.46 \pm 0.05^{\mathrm{a}}$ \\
\hline Albumin (mg/dL) & $0.52 \pm 0.21^{\mathrm{c}}$ & $0.66 \pm 0.11^{b}$ & $0.64 \pm 0.21^{b}$ & $0.75 \pm 0.01^{\mathrm{a}}$ & $0.78 \pm 0.2^{\mathrm{a}}$ \\
\hline
\end{tabular}

Note: Different letters $(\mathrm{a}-\mathrm{d})$ in the same columns indicate significant differences $(p<0.05)$.

Behavior of fish from analyzed video data shows that fish exposed to nominal sublethal and lethal concentrations of Ag-NPs exhibited some clinical signs, such as fast swimming, anxiety, a tendency to swim near the surface and, finally, death with an open mouth.

\section{Discussion}

Aquatic environments (rivers, lakes, seas) are often the last destination of many pollutants, among them, Ag-NPs [45]. Several studies have reported that Ag-NPs cause mortality in adult fish and their larvae [46-48]. Sohn et al. [49] suggested that $1.8 \mathrm{mg} \mathrm{L}^{-1}$ can be used as a mean value for lethal concentrations of Ag-NPs for Japanese rice fish (Oryzias latipes) as a model of freshwater fish. The reported concentration was lower than values obtained in the current study $\left(26.85 \mathrm{mg} \mathrm{L}^{-1}\right.$ and $6.22 \mathrm{mg} \mathrm{L}^{-1}$ for adult fish and larvae of common molly, respectively). The reason for this difference could be the dissimilarity of the test parameters. Toxicity of Ag-NPs may be dependent on the environmental or test conditions, species, age, size and diet of the organism [21,23]. Furthermore, other reasons of this difference could be solvent of commercial suspension used in the present study (Ag-NPs, Nanocid L-2000, Nanonasb Pars Co., Tehran, Iran), which, according product specifications, was distilled water. Current study results show that Ag-NPs had a slight toxicity effect to the female fish and a moderate toxicity effect on the larvae (Table 6). Based on these findings, larvae were more susceptible to Ag-NPs, which is in agreement with results reported by a previous study on CuO-NPs [50]. Massarsky et al. [51] stated that AgNPs display an ability to accumulate in some tissues and induce oxidative stress, which can result in increased mortality. Authors have also shown increased intercellular production of reactive oxygen species (ROS), as well as the destruction of DNA structure after submission to Ag-NPs. Ag-NPs can decrease WBCs and affect immune-system responses. 
Table 6. Ecotoxicity of materials for aquatic organisms, according to their $96 \mathrm{~h} \mathrm{LC}_{50}$.

\begin{tabular}{ll}
\hline Toxicity Category & Concentration $\left(\mathbf{m g ~ \mathbf { L } ^ { - 1 }}\right)$ \\
\hline Very highly toxic & $96-\mathrm{h} \mathrm{LC}_{50}<0.1$ \\
Highly toxic & $0.1<96-\mathrm{h} \mathrm{LC}_{50}<1$ \\
Moderately toxic & $1<96-\mathrm{LC}_{50}<10$ \\
Slightly toxic & $10<96-\mathrm{h} \mathrm{LC}_{50}<100$ \\
Practically nontoxic & $96-\mathrm{h} \mathrm{LC} 50>100$ \\
\hline Note: All data concerning acute pollutant concentrations are adopted from Yalsuyi et al. [34].
\end{tabular}

Our findings show that Ag-NPs prolonged parturition time and reduced reproductive success and survival rate. Several studies have reported that accumulation of metal NPs induces changes in reproductive performance [17-19]. Johari [16] reported that Ag-NPs decrease fertilization and reproduction success of rainbow trout, while another study showed that Ag-NPs did not have significant effects on fertilization capability of sea urchin sperm, although they caused morphological changes in their larvae [52]. Exposure of fish to NPs can have various negative effects on survival rate [50,53], such as inducing oxidative stress, apoptosis, inflammation and genotoxicity [54]. Seemingly, Ag-NPs are able to induce toxic changes in common molly with negative effects on the reproductive system.

Hematological parameters (RBC, WBC and hematocrit) were significantly reduced in fish exposed to Ag-NPs, especially at higher concentrations. Results for negative effects of Ag-NPs on hematology parameters are in agreement with previous studies [55]. RBCs have an important role in supplying required oxygen to the body's cells, and hematocrit is known as the volumetric percentage of RBCs in the blood that is influenced by the number and size of RBCs. Ag-NPs enter into the bloodstream via the gastrointestinal tract or gill membrane and can cause accumulation of RBCs [56], leading to oxidative stress [57]. Studies have reported toxicological effects of Ag-NPs on hematological parameters via increased peroxidation [58], induction of damage in hematopoietic tissues [59] and morphological changes in RBCs [60]. With regards to negative effects of Ag-NPs on WBC, it was reported that $\mathrm{Ag}-\mathrm{NPs}$ induced intracellular cytotoxicity via the release of toxic $\mathrm{Ag}^{+}$into immune cells [61], as well as by induction of depolarization in the mitochondrial membrane and inactivation of enzymes [62].

Results from this study show that Ag-NPs lowered the serum concentration of glucose while increasing the serum concentrations of glucose, triglycerides, albumin and total protein. Similar results were reported by a previous study [11], while in another study, conflicting results were observed [6]. The serum concentrations of total protein, albumin and glucose are good markers for the immunological and nutritional condition of fish. Albumins are the most abundant proteins in blood that regulate osmotic pressure of blood, also acting as a carrier for external compounds. Blood glucose is severely affected by stressors. Changes in serum concentrations of protein might be a good index for immunity status and liver health [63-65]. As mentioned, Ag-NPs in organisms induce stress conditions and increase the levels of reactive oxygen species. During stress, the body consumes glucose and releases proteins and lipids into blood as energy sources. Stress increases the secretion of cortisol hormones that increase glucose production from liver glycogen [11] that might be consumed and destroyed in blood flow. The increased concentration of serum triglycerides, cholesterol and protein in fish submitted to Ag-NPs might be attributed to the use of these compounds for energy supply in stressed fish [66,67].

Even though LC50 at $96 \mathrm{~h}$ was around $25 \mathrm{mg} / \mathrm{L}$, our results show that much lower concentrations can have profound negative impacts on the reproductive and blood parameters of fish. However, concentrations used were still lower in order to estimate concentrations of total silver in water in natural environments, ranging from 0.09 to $320 \mu \mathrm{g} \mathrm{L}^{-1}$ [68]. Due to the uncertainty of these estimates and the widespread use of nanoparticles in various industries, concerns about their further spread in aquatic environments are increasing [69] because, as mentioned, aquatic environments are the last destination of pollutants [45]. 


\section{Conclusions}

This study provided data and information for Ag-NP toxicity that could be profitable for the management of aquatic environments and further ecotoxicological studies. We showed that Ag-NPs in various concentrations not only have negative effects on reproductive parameters (parturition time and reproductive success) but also have adverse effects on different blood-biochemical parameters. This study opens a window for future studies on common molly fish, which should be focused on other biomarkers in order to obtain a full picture of all adverse effects of Ag-NPs.

Author Contributions: Conceptualization, S.V. and N.M.; methodology, A.M.Y. and C.F.; software, M.F.V.; validation, C.F.; formal analysis, M.F.V. and A.M.Y.; investigation, N.M.; resources, S.V.; data curation, C.F. and M.D.P.; writing-original draft preparation, S.V.; writing-review and editing, M.D.P., N.M. and A.M.Y.; supervision, C.F.; project administration, S.V. and N.M. All authors have read and agreed to the published version of the manuscript.

Funding: This research did not receive any specific grant from funding agencies in the public, commercial or not-for-profit sectors.

Institutional Review Board Statement: The study was conducted in accordance with the Declaration of Helsinki, and approved by the ethical committee of Gorgan University of Agricultural Science and Natural Resources (Ethical number 19861).

Informed Consent Statement: Not applicable.

Data Availability Statement: The datasets used in this study are available from the corresponding author on reasonable request. All data and materials are available for publication.

Acknowledgments: The authors thank Aliakbar Hedayati and all the people who helped them to complete this study.

Conflicts of Interest: The authors declare that they have no conflict of interest.

\section{References}

1. Yan, L.; Zheng, Y.B.; Zhao, F.; Li, S.; Gao, X.; Xu, B.; Weiss, P.S.; Zhao, Y. Chemistry and physics of a single atomic layer: Strategies and challenges for functionalization of graphene and graphene-based materials. Chem. Soc. Rev. 2012, 41, 97-114. [CrossRef]

2. Vajargah, M.F.; Yalsuyi, A.M.; Sattari, M.; Prokić, M.D.; Faggio, C. Effects of copper oxide nanoparticles (CuO-NPs) on parturition time, survival rate and reproductive success of guppy fish, Poecilia reticulata. J. Clust. Sci. 2020, 31, 499-506. [CrossRef]

3. Yalsuyi, A.M.; Hedayati, A.; Vajargah, M.F.; Mousavi-Sabet, H. Examining the toxicity of cadmium chloride in common carp (Cyprinus carpio) and goldfish (Carassius auratus). J. Environ. Treat. Tech. 2017, 5, 83-86.

4. Forouhar Vajargah, M.; Imanpoor, M.R.; Shabani, A.; Hedayati, A.; Faggio, C. Effect of long-term exposure of silver nanoparticles on growth indices, hematological and biochemical parameters and gonad histology of male goldfish (Carassius auratus gibelio). Microsc. Res. Tech. 2019, 82, 1224-1230. [CrossRef] [PubMed]

5. Yalsuyi, A.M.; Vajargah, M.F. Recent advance on aspect of fisheries: A review. J. Coast. Life Med. 2017, 5, 141-148. [CrossRef]

6. Kakavand, F.; Hedayati, A.; Nodeh, A.J.; Maddah, S.; Shadegan, M.R. Toxicological Effects of Silver Nanoparticles on Nile Tilapia (Oreochromis niloticus). Avicenna J. Environ. Health Eng. 2020, 7, 1-7. [CrossRef]

7. Yalsuyi, A.M.; Vajargah, M.F. Acute toxicity of silver nanoparticles in Roach (Rutilus rutilus) and Goldfish (Carassius auratus). J. Environ. Treat. Tech. 2017, 5,1-4.

8. Mohsenpour, R.; Mousavi-Sabet, H.; Hedayati, A.; Rezaei, A.; Yalsuyi, A.M.; Faggio, C. In vitro effects of silver nanoparticles on gills morphology of female Guppy (Poecilia reticulate) after a short-term exposure. Microsc. Res. Tech. 2020, 83, $1552-1557$. [CrossRef]

9. Inshakova, E.; Inshakov, O. World market for nanomaterials: Structure and trends. MATEC Web Conf. 2017, 129, 02013. [CrossRef]

10. Mahmoudabadi, S.; Farahpour, M.R.; Jafarirad, S. Effectiveness of green synthesis of silver/kaolinite nanocomposite using Quercus infectoria galls aqueous extract and its chitosan-capped derivative on the healing of infected wound. IEEE Trans. Nano Biosci. 2021, 20, 530-542. [CrossRef]

11. Vali, S.; Mohammadi, G.; Tavabe, K.R.; Moghadas, F.; Naserabad, S.S. The effects of silver nanoparticles (Ag-NPs) sublethal concentrations on common carp (Cyprinus carpio): Bioaccumulation, hematology, serum biochemistry and immunology, antioxidant enzymes, and skin mucosal responses. Ecotoxicol. Environ. Saf. 2020, 194, 110353. [CrossRef]

12. Rashidian, G.; Lazado, C.C.; Mahboub, H.H.; Mohammadi-Aloucheh, R.; Prokić, M.D.; Nada, H.S.; Faggio, C. Chemically and Green Synthesized ZnO Nanoparticles Alter Key Immunological Molecules in Common Carp (Cyprinus carpio) Skin Mucus. Int. J. Mol. Sci. 2021, 22, 3270. [CrossRef] [PubMed] 
13. Vijayakumar, S.; Vaseeharan, B.; Sudhakaran, R.; Jeyakandan, J.; Ramasamy, P.; Sonawane, A.; Padhi, A.; Velusamy, P.; Anbu, P.; Faggio, C. Bioinspired zinc oxide nanoparticles using Lycopersicon esculentum for antimicrobial and anticancer applications. J. Clust. Sci. 2019, 30, 1465-1479. [CrossRef]

14. Waalewijn-Kool, P.L.; Klein, K.; Forniés, R.M.; van Gestel, C.A. Bioaccumulation and toxicity of silver nanoparticles and silver nitrate to the soil arthropod Folsomia candida. Ecotoxicology 2014, 23, 1629-1637. [CrossRef] [PubMed]

15. Faggio, C.; Pagano, M.; Alampi, R.; Vazzana, I.; Felice, M.R. Cytotoxicity, haemolymphatic parameters, and oxidative stress following exposure to sub-lethal concentrations of quaternium-15 in Mytilus galloprovincialis. Aquat. Toxicol. 2016, 180, 258-265. [CrossRef] [PubMed]

16. Johari, S. Toxicity Effect of Colloidal Silver Nanoparticles on Fertilization Capacity and Reproduction Success of Rainbow Trout (Oncorhynchus mykiss). J. Nanomed. Res. 2014, 1, 1. [CrossRef]

17. Ninan, N.; Goswami, N.; Vasilev, K. The impact of engineered silver nanomaterials on the immune system. Nanomaterials 2020, 10, 967. [CrossRef] [PubMed]

18. Aliko, V.; Qirjo, M.; Sula, E.; Morina, V.; Faggio, C. Antioxidant defense system, immune response and erythron profile modulation in gold fish, Carassius auratus, after acute manganese treatment. Fish Shellfish Immunol. 2018, 76, 101-109. [CrossRef]

19. Gobi, N.; Vaseeharan, B.; Rekha, R.; Vijayakumar, S.; Faggio, C. Bioaccumulation, cytotoxicity and oxidative stress of the acute exposure selenium in Oreochromis mossambicus. Ecotoxicol. Environ. Saf. 2018, 162, 147-159. [CrossRef]

20. Savorelli, F.; Manfra, L.; Croppo, M.; Tornambè, A.; Palazzi, D.; Canepa, S.; Trentini, P.; Cicero, A.; Faggio, C. Fitness evaluation of Ruditapes philippinarum exposed to Ni. Biol. Trace Elem. Res. 2017, 177, 384-393. [CrossRef] [PubMed]

21. Vajargah, M.F.; Hedayati, A. Acute toxicity of trichlorofon on four viviparous fish: Poecilia latipinna, Poecilia reticulata, Gambusia holbrooki and Xiphophorus helleri (Cyprinodontiformes: Poeciliidae). J Coastal Life Med. 2014, 2, 511-514.

22. Vajargah, M.F.; Yalsuyi, A.M.; Hedayati, A. Effects of dietary Kemin multi-enzyme on survival rate of common carp (Cyprinus carpio) exposed to abamectin. Iranian J. Fisheries Sci. 2018, 17, 564-572.

23. Vajargah, M.F.; Namin, J.I.; Mohsenpour, R.; Yalsuyi, A.M.; Prokić, M.D.; Faggio, C. Histological effects of sublethal concentrations of insecticide Lindane on intestinal tissue of grass carp (Ctenopharyngodon idella). Vet. Res. Commun. 2021, 45, 373-380. [CrossRef] [PubMed]

24. Yalsuyi, A.M.; Hajimoradloo, A.; Ghorbani, R.; Jafari, V.A.; Prokić, M.D.; Faggio, C. Behavior evaluation of rainbow trout (Oncorhynchus mykiss) following temperature and ammonia alterations. Environ. Toxicol. Pharmacol. 2021, 86, 103648. [CrossRef]

25. Vajargah, M.F.; Mohsenpour, R.; Yalsuyi, A.M.; Galangash, M.M.; Faggio, C. Evaluation of Histopathological Effect of Roach (Rutilus rutilus caspicus) in Exposure to Sub-Lethal Concentrations of Abamectin. Water Air Soil Pollut. 2021, 232, 1-8. [CrossRef]

26. Vajargah, M.F. A review on the effects of heavy metals on aquatic animals. Environ. Sci. 2021, 2, 865-869. [CrossRef]

27. Alda, F.; Reina, R.G.; Doadrio, I.; Bermingham, E. Phylogeny and biogeography of the Poecilia sphenops species complex (Actinopterygii, Poeciliidae) in Central America. Mol. Phylogenetics Evol. 2013, 66, 1011-1026. [CrossRef] [PubMed]

28. Ramírez-García, A.; Ramírez-Herrejón, J.P.; Medina-Nava, M.; Hernández-Morales, R.; Domínguez-Domínguez, O. Reproductive biology of the invasive species Pseudoxiphophorus bimaculatus and Poecilia sphenops in the Teuchitlán River, México. J. Appl. Ichthyol. 2018, 34, 81-90. [CrossRef]

29. Hussain, R.; Mahmood, F.; Khan, A.; Javed, M.T.; Rehan, S.; Mehdi, T. Cellular and biochemical effects induced by atrazine on blood of male Japanese quail (Coturnix japonica). Pestic. Biochem. Physiol. 2012, 103, 38-42. [CrossRef]

30. Burgos-Aceves, M.A.; Lionetti, L.; Faggio, C. Multidisciplinary hematology as prognostic device in environmental and xenobiotic stress-induced response in fish. Sci. Total Environ. 2019, 670, 1170-1183. [CrossRef]

31. Bussons, I.N.B.; da Silva Sousa, E.; Aride, P.H.R.; Duncan, W.L.P.; Pantoja-Lima, J.; Furuya, W.M.; de Oliveira, A.T.; Bussons, M.R.F.M.; Faggio, C. Growth performance, hematological responses and economic indexes of Colossoma macropomum (Cuvier, 1818) fed graded levels of glycerol. Comp. Biochem. Physiol. Part C Toxicol. Pharmacol. 2021, 249, 109122. [CrossRef]

32. Kumar, J.; Priyadharshini, M.; Madhavi, M.; Begum, S.S.; Ali, A.J.; Musthafa, M.S.; Faggio, C. Impact of Hygrophila auriculata supplementary diets on the growth, survival, biochemical and hematological parameters in fingerlings of freshwater fish Cirrhinus mrigala (Hamilton, 1822). Comp. Biochem. Physiol. Part A Mol. Integr. Physiol. 2021, 263, 111097. [CrossRef]

33. Satheeshkumar, P.; Ananthan, G.; Senthilkumar, D.; Khan, A.B.; Jeevanantham, K. Comparative investigation on haematological and biochemical studies on wild marine teleost fishes from Vellar estuary, southeast coast of India. Comp. Clin. Pathol. 2012, 21, 275-281. [CrossRef]

34. Sharma, S.; Dar, O.I.; Singh, K.; Kaur, A.; Faggio, C. Triclosan elicited biochemical and transcriptomic alterations in Labeo rohita larvae. Environ. Toxicol. Pharmacol. 2021, 88, 103748. [CrossRef] [PubMed]

35. Mohamadi Yalsuyi, A.; Forouhar Vajargah, M.; Hajimoradloo, A.; Mohammadi Galangash, M.; Prokić, M.D.; Faggio, C. Can Betadine (10\% povidone-iodine solution) act on the survival rate and gill tissue structure of Oranda goldfish (Carassius auratus)? Vet. Res. Commun. 2021, 2021, 1-8. [CrossRef] [PubMed]

36. Yalsuyi, A.M.; Vajargah, M.F.; Hajimoradloo, A.; Galangash, M.M.; Prokić, M.D.; Faggio, C. Evaluation of behavioral changes and tissue damages in common carp (Cyprinus carpio) after exposure to the herbicide glyphosate. Vet. Sci. 2021, 8, 218. [CrossRef]

37. Amiri, M.; Etemadifar, Z.; Daneshkazemi, A.; Nateghi, M. Antimicrobial effect of copper oxide nanoparticles on some oral bacteria and candida species. J. Dent. Biomater. 2017, 4, 347.

38. Forouhar Vajargah, M.; Mohammadi Yalsuyi, A.; Hedayati, A. Acute toxicity of povidone-iodine (Betadine) in common carp (Cyprinus carpio L. 1758). Pollution 2017, 3, 589-593. 
39. Hedayati, A.; Yalsuyi, A.M.; Vajargah, M.F. Acute toxicity test as a method to assessment toxicity of pollutants. Ann. Aquac. Res. 2017, 4, 1036.

40. Vajargah, M.F.; Hedayati, A. Acute toxicity of butachlor to Rutilus rutilus caspicus and Sander lucioperca in vivo condition. Transylv. Rev. Syst. Ecol. Res. 2017, 19, 85.

41. Vajargah, M.F.; Yalsuyi, A.M.; Sattari, M.; Hedayati, A. Acute toxicity effect of glyphosate on survival rate of common carp Cyprinus carpio. Environ. Health Eng. Manag. J. 2018, 5, 61-66. [CrossRef]

42. Kodric-Brown, A.; Nicoletto, P.F. Age and experience affect female choice in the guppy (Poecilia reticulata). Am. Nat. 2001, 157, 316-323. [CrossRef] [PubMed]

43. Griffitt, R.J.; Weil, R.; Hyndman, K.A.; Denslow, N.D.; Powers, K.; Taylor, D.; Barber, D.S. Exposure to Copper nanoparticles causes gill injury and acute lethality in Zebrafish (Danio rerio). Environ. Sci. Technol. 2007, 41, 8178-8186. [CrossRef] [PubMed]

44. Kenari, A.A.; Mahmoudi, N.; Soltani, M.; Abediankenari, S. Dietary nucleotide supplements influence the growth, haematoimmunological parameters and stress responses in endangered Caspian brown trout (Salmo trutta caspius K essler, 1877). Aquac. Nutr. 2013, 19, 54-63. [CrossRef]

45. Ahmed, I.; Sheikh, Z. Comparative study of hematological parameters of snow trout Schizopyge plagiostomus and Schizopyge niger inhabiting two different habitats. Eur. Zool. J. 2020, 87, 12-19. [CrossRef]

46. Hedayati, A.; Vajargah, M.F.; Yalsuyi, A.M.; Abarghoei, S.; Hajiahmadyan, M. Acute toxicity test of pesticide abamectin on common carp (Cyprinus carpio). J. Coast. Life Med. 2014, 2, 841-844.

47. Asharani, P.; Lianwu, Y.; Gong, Z.; Valiyaveettil, S. Comparison of the toxicity of silver, gold and platinum nanoparticles in developing Zebrafish embryos. Nanotoxicology 2011, 5, 43-54. [CrossRef]

48. Powers, C.M.; Slotkin, T.A.; Seidler, F.J.; Badireddy, A.R.; Padilla, S. Silver nanoparticles alter Zebrafish development and larval behavior: Distinct roles for particle size, coating and composition. Neurotoxicol. Teratol. 2011, 33, 708-714. [CrossRef]

49. Sohn, E.K.; Johari, S.A.; Kim, T.G.; Kim, J.K.; Kim, E.; Lee, J.H.; Chung, Y.S.; Yu, I.J. Aquatic toxicity comparison of silver nanoparticles and silver nanowires. BioMed Res. Int. 2015, 2015, 12. [CrossRef]

50. Forouhar Vajargah, M.; Mohamadi Yalsuyi, A.; Hedayati, A.; Faggio, C. Histopathological lesions and toxicity in common carp (Cyprinus carpio L. 1758) induced by Copper nanoparticles. Microsc. Res. Tech. 2018, 81, 724-729. [CrossRef]

51. Yue, Y.; Behra, R.; Sigg, L.; Freire, F.P.; Pillai, S.; Schirmer, K. Toxicity of silver nanoparticles to a fish gill cell line: Role of medium composition. Nanotoxicology 2015, 9, 54-63. [CrossRef]

52. Bilberg, K.; Malte, H.; Wang, T.; Baatrup, E. Silver nanoparticles and silver nitrate cause respiratory stress in Eurasian perch (Perca fluviatilis). Aquat. Toxicol. 2010, 96, 159-165. [CrossRef]

53. Gambardella, C.; Aluigi, M.G.; Ferrando, S.; Gallus, L.; Ramoino, P.; Gatti, A.M.; Rottigni, M.; Falugi, C. Developmental abnormalities and changes in cholinesterase activity in sea urchin embryos and larvae from sperm exposed to engineered nanoparticles. Aquat. Toxicol. 2013, 130, 77-85. [CrossRef]

54. Shaw, B.J.; Handy, R.D. Physiological effects of nanoparticles on fish: A comparison of nanometals versus metal ions. Environ. Int. 2011, 37, 1083-1097. [CrossRef]

55. Wang, R.; Song, B.; Wu, J.; Zhang, Y.; Chen, A.; Shao, L. Potential adverse effects of nanoparticles on the reproductive system. Int. J. Nanomed. 2018, 13, 8487. [CrossRef]

56. Vignesh, V.; Anbarasi, K.F.; Karthikeyeni, S.; Sathiyanarayanan, G.; Subramanian, P.; Thirumurugan, R.A. superficial phytoassisted synthesis of silver nanoparticles and their assessment on hematological and biochemical parameters in Labeo rohita (Hamilton, 1822). Colloids Surf. A Physicochem. Eng. Asp. 2013, 439, 184-192. [CrossRef]

57. Ale, A.; Bacchetta, C.; Rossi, A.S.; Galdopórpora, J.; Desimone, M.F.; Fernando, R.; Gervasio, S.; Cazenave, J. Nanosilver toxicity in gills of a neotropical fish: Metal accumulation, oxidative stress, histopathology and other physiological effects. Ecotoxicol. Environ. Saf. 2018, 148, 976-984. [CrossRef]

58. Choi, J.E.; Kim, S.; Ahn, J.H.; Youn, P.; Kang, J.S.; Park, K.; Yi, J.; Ryu, D.Y. Induction of oxidative stress and apoptosis by silver nanoparticles in the liver of adult Zebrafish. Aquat. Toxicol. 2010, 100, 151-159. [CrossRef]

59. Massarsky, A.; Abraham, R.; Nguyen, K.C.; Rippstein, P.; Tayabali, A.F.; Trudeau, V.L.; Moon, T.W. Nanosilver cytotoxicity in rainbow trout (Oncorhynchus mykiss) erythrocytes and hepatocytes. Comp. Biochem. Physiol. Part C Toxicol. Pharmacol. 2014, 159, 10-21. [CrossRef] [PubMed]

60. Shaluei, F.; Hedayati, A.; Jahanbakhshi, A.; Kolangi, H.; Fotovat, M. Effect of subacute exposure to silver nanoparticle on some hematological and plasma biochemical indices in silver carp (Hypophthalmichthys molitrix). Hum. Exp. Toxicol. 2013, 32, 1270-1277. [CrossRef]

61. Sayed, A.E.D.H.; Kataoka, C.; Oda, S.; Kashiwada, S.; Mitani, H. Sensitivity of medaka (Oryzias latipes) to 4-nonylphenol subacute exposure; erythrocyte alterations and apoptosis. Environ. Toxicol. Pharmacol. 2018, 58, 98-104. [CrossRef]

62. Kettler, K.; Giannakou, C.; de Jong, W.H.; Hendriks, A.J.; Krystek, P. Uptake of silver nanoparticles by monocytic THP-1 cells depends on particle size and presence of serum proteins. J. Nanoparticle Res. 2016, 18, 1-9. [CrossRef]

63. de Souza, T.A.J.; Souza, L.R.R.; Franchi, L.P. Silver nanoparticles: An integrated view of green synthesis methods, transformation in the environment, and toxicity. Ecotoxicol. Environ. Saf. 2019, 171, 691-700. [CrossRef]

64. Alkaladi, A.; El-Deen, N.A.N.; Afifi, M.; Zinadah, O.A.A. Hematological and biochemical investigations on the effect of vitamin E and C on Oreochromis niloticus exposed to zinc oxide nanoparticles. Saudi J. Biol. Sci. 2015, 22, 556-563. [CrossRef] [PubMed] 
65. Tsipotis, E.; Shuja, A.; Jaber, B.L. Albumin dialysis for liver failure: A systematic review. Adv. Chronic Kidney Dis. 2015, 22, 382-390. [CrossRef] [PubMed]

66. Canli, E.G.; Dogan, A.; Canli, M. Serum biomarker levels alter following nanoparticle $\left(\mathrm{Al}_{2} \mathrm{O}_{3}, \mathrm{CuO}, \mathrm{TiO}_{2}\right)$ exposures in freshwater fish (Oreochromis niloticus). Environ. Toxicol. Pharmacol. 2018, 62, 181-187. [CrossRef]

67. Lupatsch, I.; Santos, G.; Schrama, J.; Verreth, J. Effect of stocking density and feeding level on energy expenditure and stress responsiveness in European sea bass, Dicentrarchus labrax. Aquaculture 2010, 298, 245-250. [CrossRef]

68. McGillicuddy, E.; Murray, I.; Kavanagh, S.; Morrison, L.; Fogarty, A.; Cormican, M.; Dockery, P.; Prendergast, M.; Rowan, N.; Morris, D. Silver nanoparticles in the environment: Sources, detection and ecotoxicology. Sci. Total Environ. 2017, 575, 231-246. [CrossRef]

69. Bone, A.J.; Colman, B.P.; Gondikas, A.P.; Newton, K.M.; Harrold, K.H.; Cory, R.M.; Unrine, J.M.; Klaine, S.J.; Matson, C.W.; Di Giulio, R.T. Biotic and abiotic interactions in aquatic microcosms determine fate and toxicity of Ag nanoparticles: Part 2-Toxicity and Ag speciation. Environ. Sci. Technol. 2012, 46, 6925-6933. [CrossRef] [PubMed] 